IRSTI 03.41.91

\author{
Bilyalova G.D. ${ }^{1}$, Tleugabulov D.T. ${ }^{2}$, Yumakayeva E.A. ${ }^{3}$ \\ ${ }^{1}$ Doctoral Candidate, e-mail: gulzat_84@inbox.ru \\ ${ }^{2}$ Doctoral Candidate, e-mail: danchitto@mail.ru \\ ${ }^{3}$ Student, e-mail: supercoolsro@gmail.com \\ L.N. Gumilyov Eurasian National University, Kazakhstan, Astana

\section{RITES AND RITUALS OF ANCIENT TURKIC PERIOD BY THE WRITTEN SOURCES}

\begin{abstract}
In this article is considered the description of rites and rituals of the ancient Turkic era by the written sources and their reflection in the design and architecture of princely memorial churches of the steppe Eurasia. Characteristics of the Bozok archaeological microdistrict as a cult center of the medieval Saryarka. The authors made an attempt to systematize written information about the cult practices of the ancient Turks. Details of ritual activities associated with the funeral-memorial cycle are recorded in Chinese dynasty chronicles, in Arabic-Persian tractates, in part in the European annals. Information about the rituals can be obtained from the texts of the Orkhon runic. Comparison and matching of these diverse multilingual sources restores the worldview of ancient Turkic-speaking ethnic groups. The article contains written evidence of the existence of special places for the performance of religious and calendar ceremonies among the ancient Turks. It could be open areas, elevations, special groves, where sacrifices were carried out. At the same time there is information about the cities and the temples built in them for holding annual calendar festivities. Thus, the involvement of narrative sources reinforces and complements the positions of archaeological reconstructions.
\end{abstract}

Key words: Archeology, Bozok, Ancient Turks, Rite, Ritual.

$$
\begin{gathered}
\text { Билялова Г.А. }{ }^{1}, \text { Тлеугабулов А.Т. }{ }^{2}, \text { Юмакаева Э.А. }{ }^{3} \\
\text { 'Аокторант, e-mail: gulzat_84@inbox.ru } \\
{ }^{2} \text { Аокторант, e-mail: danchitto@mail.ru } \\
{ }^{3} \text { студент, е-mail: supercoolsro@gmail.com } \\
\text { ^.Н. Гумилев атындағы Еуразия ұлттық, университеті, Қазақстан, Астана қ. } \\
\text { Жазбаша деректер бойынша } \\
\text { көне түркі дәуіріндегі ғұрыптар мен салттар }
\end{gathered}
$$

Мақалада көне түркі дәуіріндегі ғұрыптар мен салттардың жазбаша деректер негізінде сипатталуы және олардың Аалалық Еуразияның князьдік ғұрыптық ғибадатханаларының құрылымы мен архитектурасында көрініс табуы ұсынылған. Бозоқ археологиялық шағын ауданының ортағасырлық Сарыарқадағы ғұрыптық орталық ретіндегі сипаттамасы берілген. Авторлар ежелгі түркілердің ғұрыптық тәжірибесі туралы жазба деректерАі жүйелеуге талпыныстар жасады. Жерлеу-еске алу шараларымен байланысты ғұрыптардың кейбір ерекшеліктері қытайлық, династиялық жазбаларда, араб-парсы тілдеріндегі трактаттарда, ішінара еуропалық жазба деректерде де кездеседі. Салттар туралы орхон руникалық жазбаларының мәтіндерінде кездестіруге болады. Әртүрлі кезеңдерге жататын, әртүрлі тілде жазылған бұл деректерді салыстыру мен сәйкестендіру арқылы ежелгі түркі тілді этностардың дүниетанымын қалпына келтіруге болады. Мақалада діни және күнтізбелік шараларды жасауға арналған ерекше орындардың болғандығы туралы жазба деректер бар. Бұл құрбандық шалынатын ашық алаңдар, төбелер, ерекше тоғайлар болуы мүмкін. Сонымен қатар қалалар және оларда жыл сайынғы күнтізбелік мейрамдарды өткізуге арналып салынған ғибадатханалардың болғандығы туралы мәліметтер бар. Осылайша, жазба деректерді пайдалану археологиялық қалпына келтіруді күшейтеді және толықтырады.

Түйін сөздер: археология, Бозоқ, көне түркілер, ғұрып, салт-жора. 


\author{
Билялова Г.А. ${ }^{1}$, Тлеугабулов А.Т. ${ }^{2}$, Юмакаева Э.А. ${ }^{3}$ \\ ${ }^{1}$ Аокторант, e-mail: gulzat_84@inbox.ru \\ ${ }^{2}$ Аокторант, e-mail: danchitto@mail.ru \\ ${ }^{3}$ студент, e-mail: supercoolsro@gmail.com \\ Евразийский национальный университет им. А.Н. Гумилева, Казахстан, г. Астана \\ Обряды и ритуалы древнетюркской эпохи \\ по письменным источникам
}

\begin{abstract}
В статье представлено описание обрядов и ритуалов древнетюркской эпохи по письменным источникам и их отражение в конструкции и архитектуре княжеских поминальных храмов степной Евразии. Аана характеристика бозокского археологического микрорайона как культового центра средневековой Сарыарки. Авторы слелали попытку систематизировать письменные сведения о культовой практике древних тюрков. Аетали обрядовых действий, связанные с погребальнопоминальным циклом, зафиксированы в китайских династийных хрониках, в арабо-персоязычных трактатах, частично в европейских анналах. Сведения о ритуалах можно почерпнуть из текстов орхонской руники. Сравнение и сопоставление этих разновременных, разноязыких источников восстанавливает картину мировоззрения древних тюркоязычных этносов. Статья содержит письменные свидетельства о существовании у древних тюрков особых мест Аля отправления религиозных и календарных обрядов. Это могли быть открытые площаАки, возвышенности, особые рощи, гАе осуществлялись жертвоприношения. В то же время есть сведения о городах и построенных в них храмах, для проведения ежегодных календарных празднеств. Таким образом, привлечение сведений нарративных источников укреп^яет и Аополняет позиции археологических реконструкций.
\end{abstract}

Ключевые слова: археология, Бозок, Аревние тюрки, обряд, ритуал.

\section{Introduction}

In the period from the second half of the $\mathrm{V}$ - in the second half of the VI centuries in the steppes of Kazakhstan the history of the early Turkic era begins, the Turkic historical and cultural complex is formed. A large amount of archaeological material, accumulated over decades of expeditionary work, allows us to reconstruct the picture of historical processes of this period. However, to characterize the spiritual culture, rites and rituals of ancient Turks, it is advisable to attract written sources. They indirectly disclose the semantic content of some archaeological objects. And this comparison seems to be the most productive and allows us to consider archaeological material from a different point of view. For this we involve translations of ancient Turkic and Chinese chronicles.

The most common type of ritual monuments are ancient Turkic fences, which are a complex of quadrangular stone fences with rows of vertical columns (balbals) and standing on the east side of stone statues. These monuments date from the VI-XI centuries. Their appointment, as well as the appointment of an architectural and planning complex, open at the Bozok settlemet, which has a vivid resemblance to the cult-memorial monuments of the ancient Turks of YI-YIII centuries in Central Asia and princely memorial temples of Eastern Europe, can be tried reconstructed from written sources.
The identification of the semantic content of the spatial components of the ancient town of Bozok according to collected written information on the cult practices of the ancient Turks is the main aim of this article. This aim corresponds to the goals of exploring the historical and cultural factors of the formation of a complex socio-spatial structure of the Bozok microdistrict, as well as systematize data on the architecture and semantics of the medieval memorial temples of Eurasia, and determine the status of the ancient settlement of Bozok as a cult center of the ancient Turkic era.

\section{The Main Part}

Ancient settlement Bozok is located on the southern outskirts of the Astana city among the marshes of Ishim River's left floodplain (Akishev, 2011: 207). For the first time this settlement is mentioned in travel notes by the geologist I. Shangin, who visited this territory in 1816 . He surveyed the valleys of the Nura and Ishim rivers. Researcher wrote in his diary that on the shore of Lake Buzuk near Akmolinsk there are ruins, possibly the remains of the ancient settlement.

Today among the famous medieval towns of Eurasia there is not a monument, having the shape of a three-part composition. But exactly this planigraphy has a special meaning and a code that its builders left for us. The division into three parts, each of which had its name, was characteristically 
for to the nomadic residences of the rulers of the Turkic and Mongolian nomads from ancient times. Center was called ordu, right wing - uchuk, left wing - buzuk. These terms are fixed in the Orkhon runes. Later, they were used in the names of the administrative structures of tribal alliances and early state formations. Hence the federal division of the Kazakh Khanate on three juz and hence the names: Ak Orda, Kok Orda, Golden Horde. It can be argued that the semantics of the spatial distribution of quarters of the Bozok settlement shows the standard of an elite residence of VIII-IX centuries. An indirect argument can be the name of the lake «Buzukty» inscribed on large-scale maps of Tselinograd area (Khabdulina, 2016: 61).

Maybe the lake was named after one of the first residences of the Oguz-Kipchak in the way of their movement to the west. Despite the past hundreds of years, the term «Buzuk» has remained in the local hydronyms and preserved nowadays (Bozok, 2008:5-6].

«Bozok» is a Turkic-Oguz term, the name of the eastern part of the administrative structure of the ancient Turkic states. According to the semantic content, the Turkic-Oguz term «Buzuk» can mean a penetrating, destroying arrow (buz ok) or if we say «Bozok» it can mean a light arrow. In the ancient Turkic reading it is more legitimate to pronounce «Bozok». The etymology of the Turkic word Boz has several portable semantic meanings, among which there are concepts: untouched earth, virgin soil, feather grass (Akishev, 2011: 227).

The memory of the heroic era of the Turkic kaganates in the architecture of the settlement of Bozok remained in the unusual layout of defensive structures: the internal moat and the outer rampart. According to researchers, the original genetic idea belongs to the princely memorial temples of ancient Turks. Among them there are simple structures in the form of rectangular embankments surrounded by a moat and a rampart, on the inner site of which there are sometimes stone fences and Kagan temples, whose architecture is known from the monuments of Kulteghin and Bilge Kagan (Ambroz, 1981: 14).

So in the Orkhon inscriptions we meet the following lines: «In honor of my uncle-kagan I put at the head (of gravestones string) the» balbal «of the Kyrgyz kagan» (Malov, 1951: 39), «(In quality) of the constructor of the building (temple) and the stone with the inscription adorned with carving, officials (rockshapers) of Kagan Tabgachi and ChangSengun came» (Malov, 1951: 43). Here, for us, it is important to point out the construction of a temple and a stone with an inscription/balbal as the main funeral and memorial structures for the burial of the deceased Kultegin.

The burial rite of the ancient Turks is described in sufficient detail in the dynasty chronicle of Tang shu: «On a selected day, the horse on which the deceased rides is taken and the things he consumed along with the deceased are burned: they collect ash and bury at a certain time of the year in the grave. Died in spring and summer bury, when leaves on trees and plants begin to turn yellow and fall, died in autumn or winter bury, when flowers begin to blossom... In the building built at the grave, put painted depiction of the deceased and a description of the battles in which he was in the continuation of life. Usually, if he killed one person, put one stone. For others, the number of such stones extends to a hundred or even a thousand». From this description, which repeatedly attracted the attention of researchers, L.R. Kyzlasov concludes that the important accompanying details of Kagan temples are alleys of sculptures, balbals, stone turtles (Klyashtornyiy, 2005: 197-198).

The text of the Suisha chronicle (VII century) is of great importance for our theme: it reads (in the translation of N. Ya. Bichurin): «In the building built at the grave, put painted face of the deceased and the description of the battles in which he was in continuation of life. Usually, if he killed one person, put one stone. For others, the number of such stones extends to a hundred or even a thousand» (Kyzlasov, 1969: 37). There are two more translations of this text by Suisha, made by R.F. Its and Liu Mau- tsui. By R.F. Its: «A house is placed at the grave of a tree. Inside of it depict the face of the deceased, as well as military exploits committed by him during his lifetime. Usually, if he killed one person, put one stone and so on to hundreds and thousands» (Its, 1958: 102). Translation of Liu Mau-tsui: "Then they bury the ashes and place a wooden pillar on the grave as a commemorative sign. On the grave they build a room in which they depict the face of the deceased and scenes of battles in which the deceased took part until his death. If he once killed one person (in the battle), then one stone is put (in front of the grave). The number of stones sometimes reached up to a hundred or thousand» (Kyzlasov, 1969: 37).

The differences between the translations are insignificant, and the translation by N.Ya. Bichurin remains in force. The same is said in the Baixa chronicle (VII century): «They installed on the grave (memorable) pillar. On the grave was built a room in which the appearance of the deceased and the scenes of the battles from his life. If the deceased 
once killed one person, put one stone. At the same time, it happened that hundreds and thousands of stones were installed» (Kyzlasov, 1969: 38).

From these texts it can be seen that the Turks in the 6 th - early 7 th centuries put a row of untreated stones according to the number of dead enemies killed. This fully corresponds to the balbal of ancient Turkic inscriptions and rows of stone columns, fixed archaeologically. It is further reported that a wooden house or some room is placed in front of a row of stones, which also fully corresponds to the funeral temples with walls made of raw bricks and a tiled roof constructed for the Turks by Chinese builders on the monuments of Kultegin, Bilge-Khagan and other Khagans and nobles of the Eastern Turks.
To this type of monuments can also be attributed the memorial temple Saryg-Bulun, excavated by L.R. Kyzlasov in 1959 in Tuva (Kyzlasov, 1969: 33). The Saryg-Bulun memorial complex was a quadrangular area surrounded by a rampart and an internal moat. Size of the rampart is $36 \times 29 \mathrm{~m}$. On the western side the inner embankment had a ledge on the surface of which the remains of a wooden «temple» in the form of an octagonal yurt was excavated. The author of the excavations, L.R. Kyzlasov believed that the yurt-sanctuary was intended for funeral rites. The monument dates from the VI-VIII centuries. According to architectural details, the presence of a «temple-yurt», a wooden pillar (stela?) Saryg-Bulun has a similarity with Bozok.

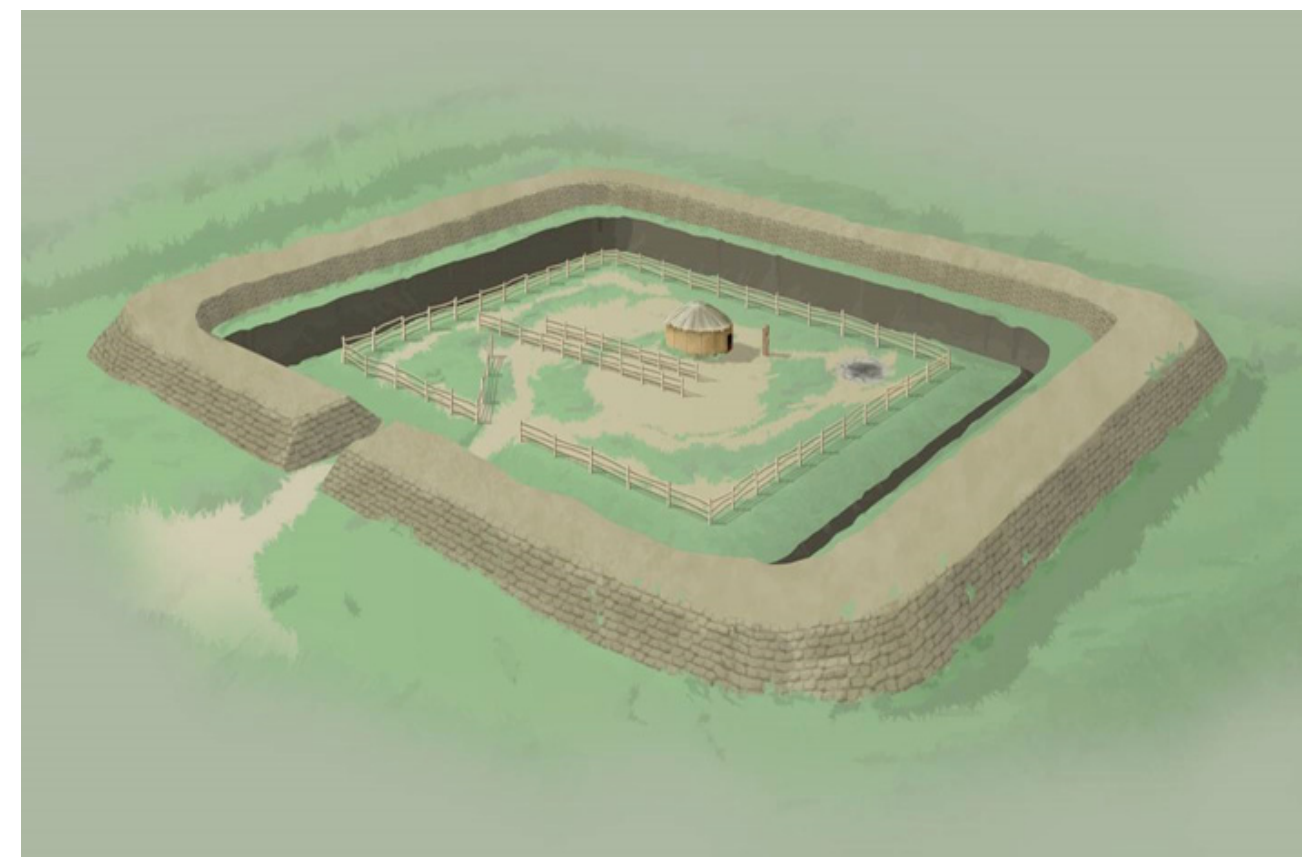

Picture 1-Reconstruction of the northern quarter on the site of Bozok

It has been repeatedly noted that the architecture of the memorial temples of the Lower Dnieper, especially Voznesenka, has analogies in Saryg-Bulun, now we can add to them the Bozok. Common to them is the enclosing of sites by a rampart-wall, the location on the site a construction of the «yurt» type, the installation of a wooden stela (in Saryg-Bulun and Bozok).

The above components of ritual structures (fence - sculpture - balbals) form a single complex, the purpose and reconstruction of which are presented by researchers in different ways. According to V.D. Kubarev, the fence is the base of the dwelling, in front of which there is a stone statue (the image of the deceased) and a row of stones-balbals (or horse standings). Participants of the ceremony sit around in front of the image of the deceased for the rite of the dead man's departure (Kubarev V., 1984: 7980).

Thus, such details of the architecture of the Bozok settlement, as the planning of defensive fortifications, the «yurt», a vertically buried pillar find analogies in the construction of cult-memorial complexes of the ancient Turkic era. This statement is confirmed by information about the funeral rite in the Orkhon inscriptions and Chinese chronicles.

In the Chinese chronicles the following description of funeral rituals is fixed: the deceased was 
placed on a ramp in a yurt. Near to the yurt were sacrificed sheep and horses. Seven times circling the yurt in, relatives each time before the entrance scraped face, mourning the deceased. On the appointed day, the horses, clothes and belongings of the deceased were burnt together with the corpse of the deceased. The collected ashes were buried at the right time: if died in the spring or summer, they waited for the grass and leaves in the trees to turn yellow, if died in autumn or winter, they waited for the onset of the summer. Then ash was buried in the dug grave. After the funeral, stones were laid and put on them a memorial pillar. The number of stones depended on the people that the deceased killed during his lifetime. Then the heads of the sacrificed animals were hung on the pillars. Over time, the funeral rite changed and the dead were buried in pits and poured a mound of earth or stone.

The religious system of the Turks is explored by written and archaeological sources. Archaeological sources are represented by burial mounds, memorial complexes (fences, statues, stelae, balbals, etc.), remains of temples, settlements. Fine sources are represented by petroglyphs, sculpture, small plastic objects, toreutics, etc. Before the adoption of Islam, the Turks, along with shamanism, had an ancient original religion - Tengrianism, whose rituals can be learned from Chinese chronicles, Turkic, Arabic, Greek sources.

Many Arab-Persian-speaking sources testify to the preservation of shamanism in the religious beliefs of the ancient Turks. The most frequently repeated texts about the Turkic sorcerers allegedly capable of causing cold and rain by magical manipulation. In the ancient Chinese chronicles of the VII century, «Weisha», «Suusu» says: «Honor devils and spirits and believe sorcerers» (Gumilyov, 1993: 156). Information from «Suishu» is not more clear: the Chinese word «xy» means a healer, a magus and a sorcerer. With whom we are dealing in this case, it is incomprehensible from the text, it is equally incomprehensible also what the spirits that the Turks worship are: whether they are spirits of ancestors or spirits of nature (Gumilyov, 1993: 165).

The Greek author of the beginning of the 7 th century Feofilat Simokat says: «The Turks above all respect fire, worship air and water, sing hymns to the earth, worship the only one who created heaven and earth and call him god. To Him as a sacrifice they bring horses, bulls and small cattle, and with their priests put those who, in their opinion, can predict the future» (Gasanov, 2002: 152).

The cult of fire among the Turks, like the Mongols, was associated with the belief in its power- ful purifying force from evil, given by Tengri. The information of the Byzantine ambassador Zemarh (568), which, before being admitted to the khan, was passed through the ceremony of purification by fire.

The proximity of the sacred positions of the ruler and shaman in the ancient Turkic period became so close that the rulers were often both shamans. Researchers pay attention to the fact that the ancient Türkic kagans themselves led religious rites. In particular, the Chinese chronicle «Zhou show» is quoted: «Every year the kagan led noble people into the cave of ancestors to make sacrifices, and in the middle decade of the 5th month they gathered on the river Tamir, to make a sacrifice to the god of Heaven» (Klyashtornyiy, 2005).

For almost one and a half millenium period (II century BC to XIV century AD) of the history of the steppe empires in them annually on a state scale grandiose public prayers were arranged sacrifices to the Great Spirit of Heaven - Tengri. These prayers were directed by the Kagans and khans themselves to the Spirit of Heaven Tengri because the power of the kagan was considered as a gift from Tengri, and therefore in the state he represented himself of the high priest, both for the people and for the nobles.

The rituals recorded in the ancient Turkic ethnic groups in the past had their different functions. And therefore, ritual actions are different. Some were accompanied by sacrifices, others were limited only to prayers. The collective rite action (ritual) of the sacrifice of Tengri was carried out in the form of an act of creation. The ritual was aimed at recreating the Cosmos at the most sacred point of its space the world tree. The ritual was performed on a spring morning in a place correlated with the center: on the mountain, near the four sacred birches. In the ritual, the east was accentuated: in this direction from the trees a big, sacred fire was kindled (Bezertinov, 2006: 80-83).

The presence of sacred places where memorial sacrifices were held may indicate the existence of ancestors' cult of ancient Turks. Thus, N.I. Zhurakuzyev notes that people, trusting in the help of the inhabitants of the upper world, bring sacrifices for them. For this reason, the ancient Turks held various ceremonies, performed sacrifices in their habitats (Zhurakuziev, 2012: 25). This hypothesis is supported by G.V. Kubarev: «Ancient Turks believe that after the death the soul continues to live. And this belief in the immortality of the soul, separated from man, became the basis of the cult of the dead and is inseparably linked with the cult of ancestors» (Kubarev G., 2005: 210). 
Prior to the adoption of world religions, the Turkic and Mongolian peoples used the calendar of a twelve-year animal cycle. In Altai, it was completely superseded in the XVIII - XIX centuries by the Orthodox calendar. In the Volga region after the adoption of the Tatars by Islam, introduced the calendar according to the Muslim calendar. But even after several centuries, also in the XVIII century, the Tatars, in parallel with the Muslims, also used the Turkic calendar. We do not know when and where this calendar was first used, but the facts of the choice of animals and their sequence of alternations in the celestial symbolism of the twelve-year animal cycle indicate that it was received from the nomadic Turks of Central Asia.

In confirmation of the calculation of time by the ancient Turks according to the animal calendar, the following lines from the Orkhon inscriptions can be cited: «Kultegin flew away (died) in the year of the sheep, on the seventeenth day; in the ninth month, on the twenty-seventh day we arranged a funeral. (Gravestone) building, carved (figures?) and a stone with the inscription (in honor of it) - we all (it) were consecrated in the year of the Monkey, in the seventh month, on the twenty-seventh day. Kültigin was dying at forty-seven. The stone ... so many carvers have brought the Togur and Eltebera» (Malov, 1951: 43).

In the traditional culture of the Turkic people an important place was always occupied by calendar customs and rituals. These were rites marking the change in the natural cycle, the transition from one season to another. But, first of all, it was the rituals associated with cattle breeding. Snowy, severe winters, with harsh winds, hot, arid summer, scarcity of natural water sources - all this combined with other factors had a huge impact on the life of the nomadic Turks. From the vagaries of nature depended not only on well-being, but on the very existence of people. On the basis of close coexistence with nature, the ancient Turkic religion Tengrianism and calendar holidays developed. A large number of Turkic customs and rituals originate in Tengrianism. This is due to the fact that the religion itself consisted of two different directions: faith and worship. Faith was turned to deified nature, the source of life.

They explained their veneration of the sun by the fact that «Tengri and his assistant Kun (Sun) direct the created world; rays of the sun are threads through which the spirits of plants communicate with the sun. The Turks twice a year sacrificed the sun-light: in the autumn and in the end of January, when the first glint of the sun showed on the peaks of the mountains».
At the heart of the creation of calendar customs and ceremonies of the Turks, three main components can be distinguished: labor activity associated with animal husbandry, worship of deified forces of nature and the cult of ancestors. Later sedentary people borrowed this calendar, adapted for their local climatic conditions and traditions. Since the calendar rituals always carried a social load, being an important part of the spiritual and cultural life of the society, the Turkic rulers in the ancient and middle ages used it as an ideology of uniting the people, turning the most important holidays into state.

There are facts that there were not just specially designated places for ceremonies, but also sacred cities that the kagan and its court attended during the state holidays. Such rituals and ceremonial actions were fixed in traditional culture, as an expression of the ethnic originality and self-awareness of the Turks.

Thus, it can be argued that the ancient monuments discovered in steppe Eurasia such as the settlements of Bozok and Saryg-Bulun, Voznesenka and Kagan temples of Central Asia archaeologically record the image and architecture of the cult centers of the ancient Turkic era. A striking expression of this is the planning and construction of the northern quarter of the settlement of Bozok. Details of it are recreated as a result of careful archaeological excavations.

The inner platform of the northern quarter with an area of more than 1200 square meters is tightly closed on all sides by a high and powerful wall of the shaft, a deep and wide moat surrounded by a wooden hedge. The width of $2.3 \mathrm{~m}$ is left in the middle of the south side (pic.1). In the center of the site stood a yurt-like structure. At $2 \mathrm{~m}$ from the entrance to it was dug a wooden «pillar» (stela?). The yurtlike structure is fenced off from the south by two rows of stolen wooden pillars. If the first row from the entrance to the quarter was short, and it could be bypassed from the west and east, the second row crossed the whole area from edge to edge. In the center of the yurt-shaped building, a ritual burial of a man with severed and displaced hands was found.

To this composite structure of the inner platform, an unconventional layout of the rampart and the moat. The design of the rampart and the moat is questionable in the performance of the protection functions. Small areas of the quarters are surrounded by the deep moat and by the rampart. The rampart was located behind the moat. The surface of the quarters was deepened further till the dense mainland soil. The edges around the perimeter of the site were cut obliquely towards the moat, and so the 
inner wall of the moat to $0.5 \mathrm{~m}$ below the exterior. In this situation it is difficult to imagine the possibilities of defense. Areas of the quarters became as if «sunken» in the rampart. From the point of view of defensive tactics this planning is ineffective. Probably, it has a special meaning.

More reasonably explain the quarters as closed for mass human habitation. Construction of the lower horizon of the northern quarter can testify in favor of using it as a sacred site, the place of some rituals. Perhaps the yurt was inhabited. The fact that in the center of it was found the ritual burial of a person, it provides an additional argument in favor of cult purpose of the northern quarter.

Filling of moats and stratigraphy of the cultural layer of the northern area indicate the duration of use, repeatedly renovation, and clean this area. This is confirmed by traces of repair wooden constructions and stratigraphy of moats. In the profiles of the pit it can be seen that after its initial construction the moat was dug twice. After a certain period of time the moats have been cleared to a depth of 2.0$2.2 \mathrm{~m}$. At that its contours was slightly offset. This update is especially evident in the moat's profiles of the eastern quarter. Here, even the top of wall of the rampart was truncated obliquely. For a long time the moat was hollow. Gradually the ground comes to the moat on both sides. A thick layer of clay came down from the side of the rampart. Gray loam came down from the side of the inner area. For the third time in already filled moat bricks were laid in two layers in the center. They are visible in the profiles at a depth of $1.0 \mathrm{~m}$ from the top. Yellow clay bricks were laid horizontally and were fastened with black humus silt solution. Gradually above this level is formed humus, alternating with layers of clay. Along the south side of the area in the second stage in the filled moat were dug pillars.

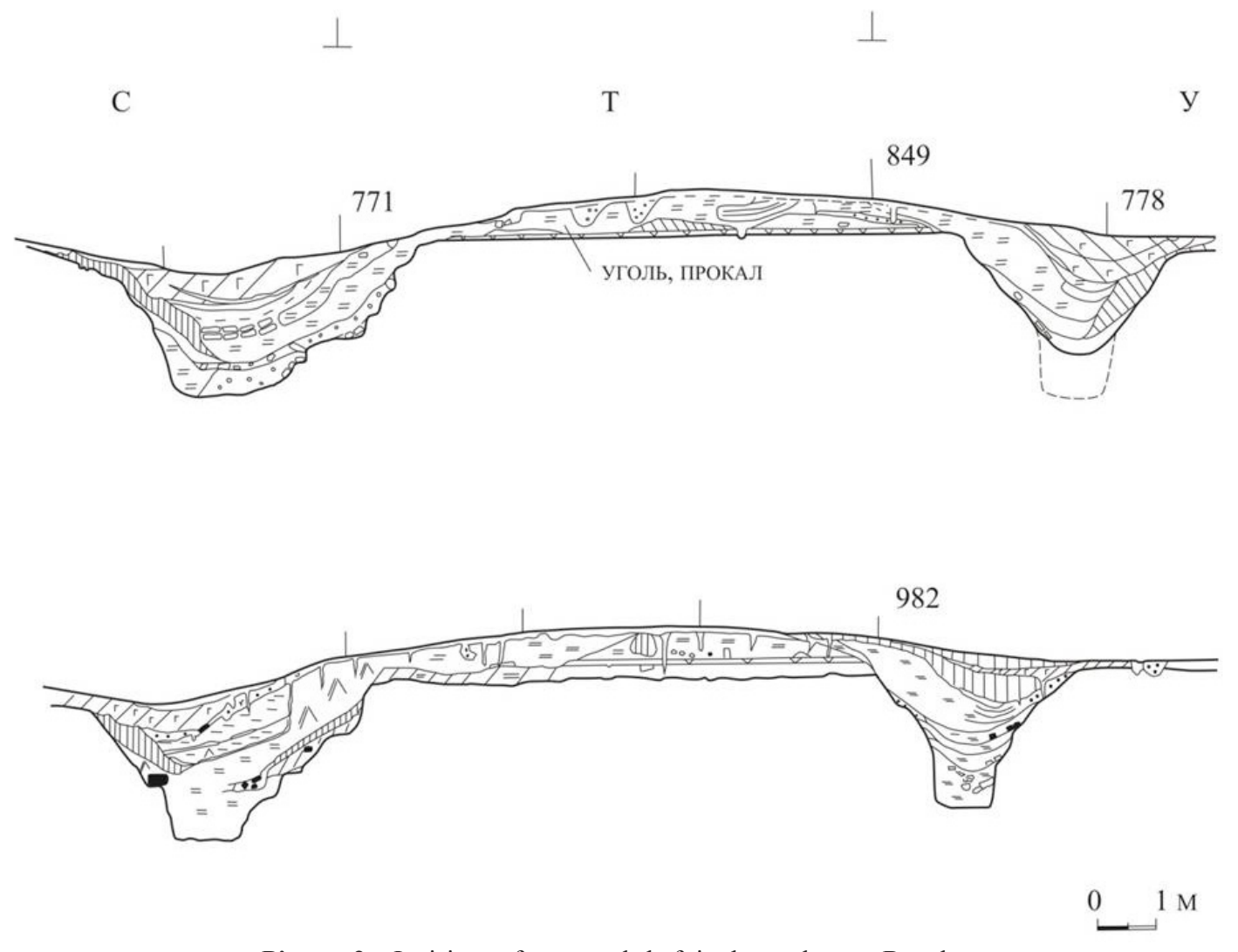

Picture 2 - Incisions of moat and shaft in the settlement Bozok

\section{Conclusion}

Architectural composition, a complex of constructions of the lower horizon of the northern quarter, semantics of planography allow to interpret the origin of the Bozok in the general flow of historical events of Turkic Kaganates' period. The Bozok settlement due to its location connects in a single chain the cult-memorial complexes of the eastern and the western edges of the Eurasian steppe, shows 
routes of movements of Turkic-speaking nomads in the way of development of new spaces. The Bozok settlement reflects the initial stage of development of the Turkic nomads of the Eurasian space. Their first residences on the new lands combine the functions of residential and sacral centers. Later periods the status of sacredness of this space was preserved in the genealogical memory of generations.

\section{References}

Akishev K.A., Khabdulina M.K. (2011). Drevnosti Astani: gorodishe Bozok [The ancient objects of Astana: Bozok city]. Astana. P. 211.

Ambroz A.A. (1981). Vostochnoevropeyskie i sredneaziatskie stepi v pervoy polovinyi VIII vv [The Eastern European and Central Asian steppes in the first half of the VIII century], // Steppes of Eurasia in the Middle Ages. Archeology of the USSR. Moscow: Science, pp. 10-23.

Bezertinov R.N. (2006). Drevnetyurkskoe mirovozzrenie «Tengrianstvo» [The Ancient Turkic worldview «Tengrianisn»]. Kazan, 2006. 164 p.

Bozok v panorame srednevekovyih kultur Evrazii: materialyi mezhdunarodnogo polevogo seminara (2008). [Bozok in the panorama of medieval cultures of Eurasia: materials of the international field seminar]. Astana. P. 285.

Gasanov Z. (2002). Tsarskie skifyi [Royal Scythians]. N.Y.: Liberty Publishing House, 2002. 493 p.

Gumilyov L.N. (1993). Drevnie tyurki [Ancient Turks]. Moscow: Science, 1993. - 253 p.

Its R.F. (1958). O kamennyih izvayaniyah v Sintszyane [About stone statues in Xinjiang], Sovetskaya Etnografiya [the Soviet Ethnography], Sovetskaya Etnologiya, 1958, №2, p. 102.

Khabdulina M.K., Tleugabulov D., Orazbayeva Z. (2016). Bozok - the Turkic cult center in Central Kazakhstan, Anthropologist, № 26, pp. 57-64.

Klyashtornyiy S.G., Savinov D.G. (2005). Stepnyie imperii drevney Evrazii [Steppe empires in the ancient Eurasia]. St. Petersburg: Philological Faculty of St. Petersburg State University, 2005. 346 p.

Kubarev G.V. (2005). Kultura drevnih tyurok Altaya. Po materialam pogrebalnyih pamyatnikov [The culture of the ancient Turks. On the materials of burial sites]. Novosibirsk: Publishing house of the Institute of Archeology and Ethnography of the SB RAS. 2005. P. 400.

Kubarev V.D. (1984). Drevnetyurkskie izvayaniya Altaya [The Ancient Turkic stelaes of Altai]. Novosibirsk, 1984. 230 p.

Kyzlasov L.R. (1969). Istoriya Tuvyi v srednie veka [The history of Tuva in the Middle Ages]. Moscow: MSU. 212 p.

Malov S.E. (1951). Pamyatniki drevnetyurkskoy pismennosti. Tekstyi i issledovaniya Sites of Ancient Turkic scripts. Texts and researches]. Moskva-Leningrad, 1951. $451 \mathrm{p}$.

Zhurakuziev N.I. (2012). Predstavleniya drevnih tyurok o mirozdanii (na primere pamyatnika v chest Kyul-tegina i pamyatnika s Elegesha) [The Ancient Turkic perceptions on the universe (with a case study of Kultegin stelae and a site from Elegash]. Bulletin of Chelabinsk State University, № 2 (256), 23-26. 